\title{
ACYLSUGARS IN TOMATO LEAFLETS CONFER RESISTANCE TO THE SOUTH AMERICAN TOMATO PINWORM, Tuta absoluta Meyr
}

\author{
Juliano Tadeu Vilela de Resende ${ }^{1 *}$; Wilson Roberto Maluf ${ }^{2}$; Marcos Ventura Faria ${ }^{1}$; Alessandra \\ Zawadzki Pfann ${ }^{1}$; Ildon Rodrigues do Nascimento ${ }^{1}$ \\ ${ }^{1}$ UNICENTRO - Depto. de Agronomia - Centro Politécnico, C.P. 3010 - 85040-080 - Guarapuava, PR - Brasil. \\ ${ }^{2}$ UFLA - Depto de Agricultura, C.P. 37 - 37200-000 - Lavras, MG - Brasil. \\ *Corresponding author <jvresende@uol.com.br>
}

\begin{abstract}
Acylsugars present in the accession 'LA716' of Lycopersicon pennellii play an important role in the resistance to Tuta absoluta. This paper investigates the possible association between the resistance to T. absoluta and the acylsugar contents in $\mathrm{F} 2$ and $\mathrm{F} 2 \mathrm{BC} 1$ tomato plants derived from the interspecific crossing between L. esculentum 'TOM-584' and L. pennellii 'LA716'. From the F2 population, four high acylsugars and one low acylsugars plants were selected and tested for Tuta absoluta resistance along with parental lines TOM-584 and LA-716, and with the checks TOM-600 (high 2-tridecanone line with resistance to T. absoluta) and TOM-556 (low acylsugar line). The genotypes were tested under natural field infestation and were evaluated for overall plant damage, leaflet lesion type and percent of attacked leaflet. Four plants from $\mathrm{F} 2 \mathrm{BC} 1\left[=\left(\right.\right.$ Lycopersicon esculentum 'TOM- $\left.\left.584^{\prime} \times \mathrm{F}_{2}\right)\right]$ were selected for high acylsugars and two for low acylsugars, and tested in greenhouse cages infested with $T$. absoluta. These genotypes were evaluated with the parental lines and the checks for oviposition ten days after infestation, and for leaflet lesion type and overall plant damage at four different dates. The F2 genotypes BPX-370Bpl\#25, BPX$370 \mathrm{Bpl} \# 30$ and BPX-370Bpl\#79, the F2BC1 genotypes BPX-370B pl\#30-380 and BPX-370B pl\#30-271 and the wild accession LA716 had good levels of resistance to Tuta absoluta. The resistance level increased with longer exposition time to the acylsugars, both in the field and in the cage tests. Acylsugar contents seemed to be highly and negatively correlated with the traits related to the pinworm resistance.

Key words: Lycopersicon pennellii, Lycopersicon esculentum, allelochemical, plant breeding
\end{abstract}

\section{ACILAÇÚCARES PRESENTES EM FOLÍOLOS DE TOMATEIRO CONFEREM RESISTÊNCIA À TRAÇA DO TOMATEIRO, Tuta absoluta Meyr}

\begin{abstract}
RESUMO: Os acilaçúcares presentes no acesso 'LA716' de Lycopersicon pennellii exercem um papel importante na resistência a Tuta absoluta. Foi avaliada a associação entre níveis de resistência à $T$. absoluta e o nível de acilaçúcares em plantas das gerações F2 e F2RC1 do cruzamento interespecífico $L$. esculentum 'TOM-584' $\times$ L. pennellii 'LA-716'. Na população F2 foram selecionados 4 genótipos com alto teor de acilaçúcares e um com baixo teor. Esses genótipos seleccionados, juntamente com as linhagens parentais e as testemunhas TOM-600 (linhagem com alto teor de 2-tridecanona e resistente a T. absoluta) e TOM-556 (linhagem com baixo teor de acilaçúcares) foram submetidos à infestação natural da traça no campo e avaliados quanto a danos na planta, lesões nos folíolos e porcentagem de folíolos atacados. Na população F2RC1 $\left[=\left(\right.\right.$ Lycopersicon esculentum 'TOM- 584 ' $\left.\left.\times \mathrm{F}_{2}\right)\right]$ foram selecionados 4 genótipos com altos teores de acilaçúcares nos folíolos e dois genótipos com baixos teores. Esses genótipos, juntamente com as linhagens parentais e as testemunhas, foram submetidos à infestação em gaiolas, em casa de vegetação. Avaliou-se a ovoposição da traça, os danos na planta e lesões1nos folíolos. Os genótipos $\mathrm{F}_{2} \mathrm{BPX}-370 \mathrm{Bpl} \# 25$, BPX-370Bpl\#30, BPX$370 \mathrm{Bpl} \# 79$ e $\mathrm{F}_{2} \mathrm{RC}_{1}$ BPX-370B pl\#30-380 e BPX-370B pl\#30-271, a exemplo do acesso selvagem LA-716, demonstraram bons níveis de resistência. Com o aumento do tempo de exposição à traça, o efeito dos acilaçúcares nos folíolos mostrou- se mais efetivo. Os teores de acilaçúcares mostraram-se alta e negativamente correlacionados com as características avaliadas, relacionadas à resistência à traça.

Palavras-chave: Lycopersicon pennellii, Lycopersicon esculentum, aleloquímicos, melhoramento genético
\end{abstract}

\section{INTRODUCTION}

Viscous allelochemicals in the accession
'LA716' of Lycopersicon pennellii, are basically a mixture of glucose and sucrose esters of fatty acids. These phytochemicals, named acylsugars, play important role

Sci. Agric. (Piracicaba, Braz.), v.63, n.1, p.20-25, Jan./Feb. 2006 
in the resistance to tomato pests, and constitute approximately $90 \%$ of the type IV glandular trichomes secretion (Fobes et al., 1985). Cultivated tomato does not accumulate high levels of acylsugars in the leaflets. However, plants derived from the interespecific cross between L. esculentum and L. pennelli 'LA716' can be selected for moderate or high levels of acylsugars.

Recessive alleles of Lycopersicon pennellii 'LA 716' are responsible for the high levels of acylsugars and the value 1.36 for the estimated number of genes suggests monogenic heredity (Resende et al., 2002), similar to the result obtained by Lenke \& Mutschler (1984), who observed that the trait glandular trichoma type IV is controlled by two genes. An additive-dominant model adequately explained the variation found in the data, and there was no evidence of epistatic gene action. The estimate of the mean degree of dominance was -0.74 , indicating that recessive allele(s) present in 'LA 716' are responsible for the high acylsugars content. However, the possibility of existence of modifying genes was not excluded (Resende et al., 2002).

A moderately high, broad-sense heritability $(0.48)$ is found for the trait, indicating that a major portion of the variation among plants is genetic (Resende et al., 2002). Generally, the heritability of the resistance to arthropods-pests does not show high values. That occurs because of the difficulty of an environmental control of an evaluation system that embodies not only the plant, but also the arthropod-pest (Resende et al., 2002).

The current paper has the objective of studying the possible relationship between tomato levels of acylsugars in the leaflets and the resistance to the South American tomato pinworm Tuta absoluta (Meyrick, 1917) (syn. Scrobipalpula absoluta, Scrobipalpuloides absoluta), one of the most important pests of tomato crops in Brazil.

\section{MATERIAL AND METHODS}

Two trials evaluated the resistance of tomato genotypes to tomato pinworm, Tuta absoluta. Genotypes were selected for their righ levels of acylsugar in the leaflets, as recommended by Resende et al. (2002). The F2 and F2BC1 populations were obtained from interspecific cross between the breeding line Lycopersicon esculentum Mill. 'TOM-584' and Lycopersicon pennellii 'LA716', a source of pests resistance, with high levels of acylsugars.

Test of F2 (Lycopersicon esculentum 'TOM-584' $\times$ Lycopersicon pennellii 'LA716') plants

Five genotypes were selected out of 250 plants from the F2 (Lycopersicon esculentum 'TOM-
584 ' $\times$ Lycopersicon pennellii 'LA716') population; four genotypes were selected for high level of acylsugars (BPX-370 pl\#30; BPX-370 pl\#25; BPX$370 \mathrm{pl} \# 79$; and $\mathrm{BPX}-370 \mathrm{pl} \# 10$ ), and one for low level (BPX-370 pl\#226). These plants were propagated via rooted axillary shoot cuttings, and along with the parental lines and the check breeding lines, TOM-600 and TOM-566, were subjected to natural infestation with the tomato pinworm in greenhouse cages. The breeding line TOM-600 has a Santa Clara background, known for its low level of acylsugars, and selected for high levels of 2-tridecanone from the initial crossing with Lycopersicon hirsutum var. glabratum 'PI 134417'; the breeding line TOM-566 has a Santa Clara background, with low level of acylsugars, and tospovirus-resistance, from the accession 'Rey de los Tempranos'.

Trials were set up in randomized complete block design, one plant per experimental unit $(n=4)$. Three evaluations were performed at different dates: at pre-blossom period and at every 15 days. Genotypes were evaluated by three evaluators, according to the scoring system of Barbosa (1994) and Labory (1996), for the following parameters: overall plant damage (OPD), leaflet lesion type (LLT), and percent of attacked leaflets (PLA).

\section{Description of Scores}

Overall Plant Damage (OPD) - $0=$ no leaf damage; $1=0.1$ to $5 \%$ of total leaf area damaged, small, non-coalescent lesions; $2=5.1$ to $20 \%$ of total leaf area damaged, small to medium-size, non-coalescent lesions; $3=20.1$ to $50 \%$ of leaf area damaged, medium to large-size lesions; $4=50$ to $80.1 \%$ of leaf area damaged, numerous, large, coalescent lesions; 5 $=$ more than $80.1 \%$ of leaf area damaged, completely deformed plants.

Leaflet Lesion Type (LLT) - 0 = no lesion; $1=$ small, rare lesions; $2=$ small to medium-size lesions, rare, often towards the leaflet borders; 3 = medium to large-size lesions, coalescent; deformed leaflet borders; 4 = large-size lesions, coalescent; deformed leaflets; 5 = whole leaflet surface damaged.

Percent of Attacked Leaflets (PLA) - $0=$ no leaflets attacked; $1=0.1$ to $5 \%$ leaflets attacked; $2=$ 5.1 to $20 \%$ leaflets attacked; $3=20.1$ to $50 \%$ leaflets attacked; $4=50.1$ to $80 \%$ leaflets attacked; $5=$ more than $80 \%$ leaflets attacked.

The mean values of the three evaluators scores, at each evaluation date, were submitted to analysis of variance. 
Test of F2BC1 plants $\{=[$ L.esculentum 'TOM-584' $x$ $\mathrm{F}_{2}$ (L.esculentum 'TOM'584' $\times$ L.pennellii 'LA716')]\}

Four plants selected for high levels of acylsugars in the $\mathrm{F}_{2}$ population were backcrossed with the recurrent parent 'TOM-584'. The four F2BC1 populations were composed of 150 plants each. Those 600 plants were analyzed for acylsugars contents (Resende et al., 2002), and six genotypes were selected: four with high levels of acylsugars (BPX-370B pl\#30-380; BPX-370B pl\#30-275; BPX-370B pl\#25271; and BPX-370B pl\#79-278), and two with low levels (BPX-370B pl\#30-02; BPX-370B pl\#30-142). These plants, along with parentals TOM-584 and LA716 , and checks genotypes, were cloned and infested with the tomato pinworm in cages, greenhouse conditions, 50 days after cloning.

Leaflets with T. absoluta larvae were collected in commercial tomato crops at Lagoa Dourada-MG $\left(20^{\circ} 47^{\prime} 26^{\prime \prime} \mathrm{S}, 43^{\circ} 28^{\prime} 23^{\prime \prime} \mathrm{W}\right.$; altitude $\left.1,000 \mathrm{~m}\right)$ and maintained in laboratory until adults emergency. Adults were then transferred to cages for multiplication in tomato plants, cultivar Santa Clara. Classification by sex was done after insects multiplication in laboratory (Coelho \& França, 1987), and the tomato genotypes infestation was done at proportion 1 male: 1.32 female (Haji et al., 1988), a total of 10 males and 14 females per cage. The experiment was set up in completely randomized block design $(n=3)$, each genotype (plant) representing one experimental unit. The genotypes were evaluated for OPD, LLT and PLA at 20, 30, 40, and 50 days after infestation. Ten days after infestation, oviposition was evaluated through the number of eggs in the lower, medium, and upper third of the plants.

\section{RESULTS AND DISCUSSION}

The level of acylsugars in the accession LA716 was circa 2.25 times higher than the level of acylsugars in 'TOM-584' in the first experiment (Table 1 ), and circa 4.32 times higher in the second experiment (Table 3).

\section{Tests on F2 plants (Lycopersicon esculentum $\times$ Lycopersicon pennellii)}

The $\mathrm{F}_{2}$ genotypes selected for high level of acylsugars showed good levels of resistance to Tuta absoluta, similarly to the wild taxon LA-716, and independently of the evaluation date (Table 1). The higher average score of plant damage of these genotypes at the third evaluation date corresponded to a maximum $20 \%$ of damage, against more than $50 \%$ for genotypes TOM-556 and TOM-584. These three genotypes had the same behavior for LLT and PLA (Table 2 ). The relationship between the levels of acylsugars in leaflets and the damages caused by the pinworm were negative, and increased in absolute values during the time of exposition to the insect: at the third evaluation date, the correlation values were -0.99 , 0.89 , and -0.88 for OPD, LTT and PLA, respectively (Tables 1 and 2).

Tests on F2BC1 plants $\{=[$ L.esculentum 'TOM-584'x $\mathrm{F}_{2}$ (L.esculentum 'TOM'584'x L.pennellii 'LA716')]\}

The $\mathrm{F}_{2} \mathrm{BC}_{1}$ genotypes BPX-370B pl\#25-271 and $\mathrm{BPX}-370 \mathrm{~B}$ pl\#30-380, selected for high level of acylsugars, did not differ $(P<0.05)$ from the wild parent LA-716 OPD, independently of the evaluation date (Table 4), demonstrating good level of resistance to the pinworm. These same genotypes were superior to the

Table 1 - Selected $\mathrm{F}_{2}$ plants: Mean acylsugars content, plant damage and their linear correlations.

\begin{tabular}{|c|c|c|c|c|}
\hline \multirow[b]{2}{*}{ Genotypes } & \multirow{2}{*}{$\begin{array}{l}\text { Level of } \\
\text { acylsugars }\end{array}$} & \multicolumn{3}{|c|}{ Plant damage (OPD) Evaluation dates } \\
\hline & & $\begin{array}{l}\text { Dec. } 15 \text { to } 20 \text {, } \\
2000\end{array}$ & $\begin{array}{c}\text { Jan. } 3 \text { to } 5 \text {, } \\
2001\end{array}$ & $\begin{array}{c}\text { Jan. } 25 \text { to } 30 \\
2001\end{array}$ \\
\hline & $\left.(\mathrm{nmol} \mathrm{cm})^{-2}\right)^{2}$ & & & \\
\hline LA-716 & $63.8 \mathrm{bc}$ & $0.24 \mathrm{a}^{1}$ & $0.58 \mathrm{a}$ & $0.75 \mathrm{a}$ \\
\hline TOM-584 & $28.3 \mathrm{cde}$ & $1.50 \mathrm{~b}$ & $2.00 \mathrm{~b}$ & $3.33 \mathrm{c}$ \\
\hline TOM-556 & --- & $0.83 \mathrm{a}$ & $2.00 \mathrm{~b}$ & $3.25 \mathrm{c}$ \\
\hline TOM- 600 & -- & $0.41 \mathrm{a}$ & $1.16 \mathrm{a}$ & $0.91 \mathrm{a}$ \\
\hline BPX-370 pl\# 226 (= low 1) & $20.6 \mathrm{de}$ & $0.58 \mathrm{a}$ & $1.75 \mathrm{~b}$ & $2.50 \mathrm{~b}$ \\
\hline BPX-370 pl\# 10 (= high 4$)$ & $60.8 \mathrm{bcd}$ & $1.25 \mathrm{~b}$ & $1.91 \mathrm{~b}$ & $2.16 \mathrm{~b}$ \\
\hline BPX-370 pl\# 25 (= high 3$)$ & $78.6 \mathrm{~b}$ & $0.49 \mathrm{a}$ & $1.00 \mathrm{a}$ & $2.00 \mathrm{~b}$ \\
\hline BPX-370 pl\# 30 (= high 2$)$ & $131.4 \mathrm{a}$ & $0.41 \mathrm{a}$ & $0.75 \mathrm{a}$ & $0.91 \mathrm{a}$ \\
\hline BPX-370 pl\# 79 (= high 1) & $136.3 \mathrm{a}$ & $0.75 \mathrm{a}$ & $1.33 \mathrm{a}$ & $1.58 \mathrm{a}$ \\
\hline \multicolumn{2}{|c|}{ Linear correlations $(\mathrm{r})$ (acylsugars $\times$ damages levels) } & $-0.23^{\mathrm{ns}}$ & $-0.68^{\mathrm{ns}}$ & $-0.90 *$ \\
\hline
\end{tabular}

${ }^{1}$ Means separation by the Scott Knott test $(\alpha=0.05)$. ${ }^{2}$ Means separation by the Duncan test $(\alpha=0.05)$. ${ }^{*}$ Significant by F test $(\alpha=5 \%)$. 
Table 2 - Selected $\mathrm{F}_{2}$ plants: Leaflet lesion scores, percentage leaflets attacked and the linear correlations acylsugars $\times$ leaflet lesions.

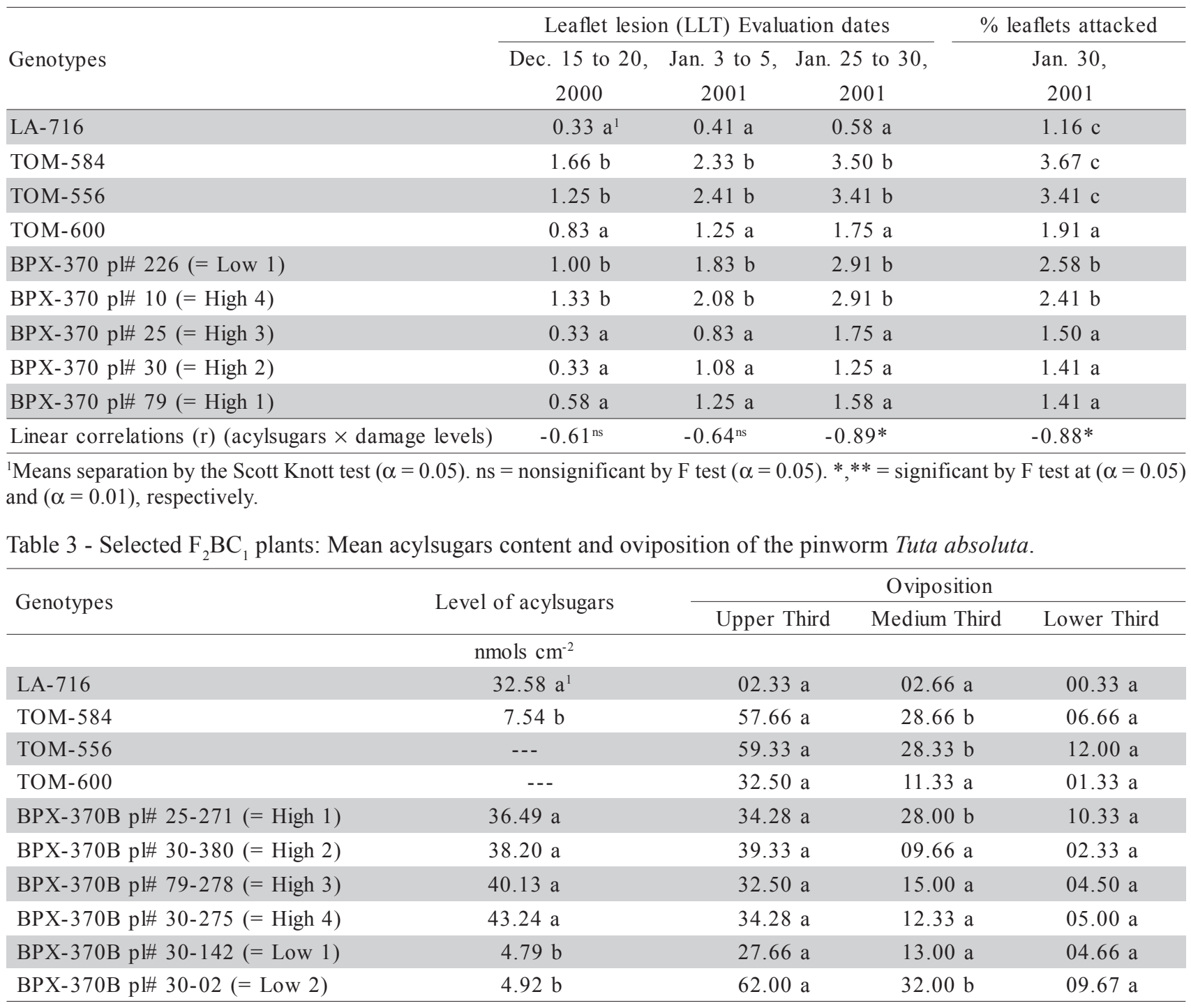

${ }^{1}$ Means separation by the Scott Knott test $(\alpha=0.05)$.

Table 4 - Selected $\mathrm{F}_{2} \mathrm{BC}_{1}$ plants: Plant damage scores and the linear correlations acylsugars $\times$ plant damage.

\begin{tabular}{lcccc}
\hline \multirow{2}{*}{ Genotypes } & \multicolumn{4}{c}{ Plant damage (PLA) Evaluation dates } \\
\cline { 2 - 5 } & Jul. 25, 2002 & Aug. 05, 2002 & Aug. 15, 2002 & Aug. 25, 2002 \\
\hline LA-716 & $0.22 \mathrm{a}^{1}$ & $0.55 \mathrm{a}$ & $0.88 \mathrm{a}$ & $1.55 \mathrm{a}$ \\
TOM-584 & $0.66 \mathrm{a}$ & $3.00 \mathrm{~b}$ & $4.11 \mathrm{~b}$ & $4.77 \mathrm{~d}$ \\
TOM-556 & $0.66 \mathrm{a}$ & $2.55 \mathrm{~b}$ & $3.66 \mathrm{~b}$ & $4.88 \mathrm{~d}$ \\
TOM-600 & $1.11 \mathrm{a}$ & $1.66 \mathrm{a}$ & $2.11 \mathrm{a}$ & $2.22 \mathrm{~b}$ \\
BPX-370B pl\# 25-271 (= High 1) & $0.77 \mathrm{a}$ & $1.44 \mathrm{a}$ & $1.44 \mathrm{a}$ & $1.22 \mathrm{a}$ \\
BPX-370B pl\# 30-380 (= High 2) & $0.88 \mathrm{a}$ & $1.33 \mathrm{a}$ & $1.88 \mathrm{a}$ & $1.44 \mathrm{a}$ \\
BPX-370B pl\# 79-278 (= High 3) & $1.16 \mathrm{a}$ & $2.00 \mathrm{a}$ & $3.66 \mathrm{~b}$ & $3.33 \mathrm{c}$ \\
BPX-370B pl\# 30-275 (= High 4) & $2.44 \mathrm{~b}$ & $3.22 \mathrm{~b}$ & $3.22 \mathrm{~b}$ & $2.88 \mathrm{~b}$ \\
BPX-370B pl\# 30-142 (= Low1) & $2.44 \mathrm{~b}$ & $3.23 \mathrm{~b}$ & $4.11 \mathrm{~b}$ & $4.66 \mathrm{~d}$ \\
BPX-370B p\#\# 30-02 (= Low 2) & $2.00 \mathrm{~b}$ & $2.77 \mathrm{~b}$ & $3.88 \mathrm{~b}$ & $4.22 \mathrm{~d}$ \\
\hline Correlations (r): (acylsugars $\times$ plants damages) & $-0.51^{\text {ns }}$ & $-0.51^{\text {ns }}$ & $-0.59^{\text {ns }}$ & $-0.75^{*}$ \\
\hline
\end{tabular}

${ }^{1}$ Means separation by the Scott Knott test $(\alpha=0.05)$. *Significant by F test $(\alpha=0.05)$. 
other genotypes selected for high level of acylsugars for LLT at the third and fourth evaluation date, and the average score for LLT of the genotype BPX-370B pl\#25-271, at the last evaluation, was not different $(P<0.05)$ from the parent LA-716 (Table 5). Genotypes with high level of acylsugars, BPX-370B pl\#79278 and BPX-370B pl\#30-275, had higher levels of plant damage and scores for leaflets lesions than those derived from LA-716, and were less damaged $(P$ $<0.05)$ than the susceptible checks TOM-584 and TOM-556 (Tables 4 and 5), and genotypes BPX-370B pl\#30-142 and BPX-370B pl\#30-02, selected for low level of acylsugars.

From the second date of evaluation forth, genotypes BPX-370B pl\#30-142 and BPX-370Bpl\#3002 , selected for low levels of acylsugars, had the same behavior of recurrent parent TOM-584 and the check TOM-556, both with low levels of acylsugars in leaflets, regarding OPD (Table 4) and LLT (Table 5). The negative correlation between the levels of acylsugars of $\mathrm{F} 2 \mathrm{BC} 1$ genotypes and the plant damage, at the last evaluation date, was relatively high $(\mathrm{r}=-0.75)$, that is, the selection of genotypes with high level of acylsugars in leaflets indirectly select for genotypes potentially less damaged by the tomato pinworm (Table 4).

Regarding oviposition, no differences between treatments were observed $(P<0.05)$, considering the average amount of eggs laid on the upper and lower third of the plants (Table 3). In the medium third of the plants, genotypes LA- 716 and TOM-600 did not differ $(P<0.05)$ regarding average amount of eggs laid by the pinworm. However, these genotypes were more efficient in repelling oviposition than genotypes TOM584 and TOM- 556, both with low level of acylsugars in the leaflets (Table 3). Genotypes BPX-370B pl\#30-
380, BPX-370B pl\#79-278, and BPX-370B pl\#30-275, presented lower oviposition $(P<0.05)$ than the parent TOM-584 on the medium third, but did not differ $(P<0.05)$ from the wild parent LA-716. There was no clear association between levels of acylsugars and mechanisms of non-preference for oviposition. The existence of F2BC1 genotypes BPX-370B pl\#25-271

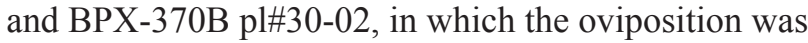
relatively high, does not indicate that eggs will necessarily hatch and larvae fully develop. As a matter of fact, independently of the levels of oviposition, the scores for plants damage and leaflets lesions were low in genotypes with high levels of acylsugars. High level of oviposition, followed by low level of damage, apparently indicate the occurrence of antibiosis-type resistance mechanism. As the infestation progressed, the allelochemicals in the leaflets were more effective against the insect. The correlations values at the fourth date of evaluation were -0.75 and -0.71 , for OPD and LLT, respectively (Tables 4 and 5).

The evaluation, both in the field and in cages, proved the efficiency of the indirect selection of tomato genotypes with high level of acylsugars to increase the level of resistance to the tomato pinworm Tuta absoluta. In both experiments, the accession $L$. esculentum TOM-600, although had low contents of acylsugars in the leaflets, had the same behavior as the selected genotypes for high levels of acylsugars (Tables 1 to 5), probably because of its high level of 2tridecanone, another allelochemical that confers resistance to pest arthropodes (Barbosa, 1994).

Other allelochemicals have been evaluated for their ability to mediate resistance to tomato pinworm. Azevedo et al. (1999) evaluated F2 selected plants for high levels of zingiberene from the interspecific cross-

Table 5 - Selected $\mathrm{F}_{2} \mathrm{BC}_{1}$ plants: Lesions in leaflets scores and the linear correlations acylsugars $\times$ lesions in leaflets.

\begin{tabular}{lcccc}
\hline \multirow{2}{*}{ Genotypes } & \multicolumn{4}{c}{ Lesions in leaflets Dates } \\
\cline { 2 - 5 } & Jul. 25, 2002 & Aug. 05, 2002 & Aug. 15, 2002 & Aug. 25, 2002 \\
\hline LA-716 & $0.11 \mathrm{a}^{\mathrm{1}}$ & $0.66 \mathrm{a}$ & $0.88 \mathrm{a}$ & $1.55 \mathrm{a}$ \\
TOM-584 & $0.66 \mathrm{a}$ & $3.22 \mathrm{~b}$ & $4.00 \mathrm{c}$ & $4.89 \mathrm{~d}$ \\
TOM-556 & $0.88 \mathrm{a}$ & $2.88 \mathrm{~b}$ & $3.77 \mathrm{c}$ & $4.77 \mathrm{~d}$ \\
TOM-600 & $1.33 \mathrm{a}$ & $1.66 \mathrm{a}$ & $2.66 \mathrm{~b}$ & $2.55 \mathrm{~b}$ \\
BPX-370B pl\# 25-271 (= High 1) & $0.88 \mathrm{a}$ & $1.22 \mathrm{a}$ & $1.88 \mathrm{~b}$ & $1.55 \mathrm{a}$ \\
BPX-370B pl\# 30-380 (= High 2) & $0.88 \mathrm{a}$ & $1.44 \mathrm{a}$ & $2.44 \mathrm{~b}$ & $2.33 \mathrm{~b}$ \\
BPX-370B pl\# 79-278 (= High 3) & $1.00 \mathrm{a}$ & $1.77 \mathrm{a}$ & $3.66 \mathrm{c}$ & $3.88 \mathrm{c}$ \\
BPX-370B pl\# 30-275 (= High 4) & $2.11 \mathrm{~b}$ & $3.33 \mathrm{~b}$ & $3.44 \mathrm{c}$ & $3.22 \mathrm{c}$ \\
BPX-370B pl\# 30-142 (= Low 1) & $2.22 \mathrm{~b}$ & $3.11 \mathrm{~b}$ & $3.33 \mathrm{c}$ & $4.65 \mathrm{~d}$ \\
BPX-370B pl\# 30-02 (= Low 2) & $2.00 \mathrm{~b}$ & $2.88 \mathrm{~b}$ & $4.11 \mathrm{c}$ & $4.55 \mathrm{~d}$ \\
\hline Correlations (r): (acylsugars $\times$ lesions in leaflets) & $-0.62^{\text {ns }}$ & $-0.49^{\text {ns }}$ & $-0.45^{\text {ns }}$ & $-0.71^{\text {ns }}$ \\
\hline
\end{tabular}

${ }^{1}$ Means separation by the Scott Knott test $(\alpha=0.05)$. ns $=$ Nonsignificant by F test $(\alpha=0.05)$. 
ing between Lycopersicon esculentum 'TOM 556' and Lycopersicon hirsutum var. hirsutum 'PI-127826'. The parental genotype 'PI-127826' and the selected genotypes with high level of zingiberene were not significantly different. However, they were different from the parent 'TOM-556' for OPD, LLT and PLA, confirming the effective action of this allelochemical in the resistance to pinworm by a non-preference mechanism. Labory (1996) and Maluf et al. (1997) reported that selected plants for high levels of the allelochemical 2tridecanone, obtained from the interspecific crossing between Lycopersicon esculentum 'TSWV-547' and Lycopersicon hirsutum var glabratum 'PI 134417', were highly resistant to tomato pinworm infestation. According to Barbosa (1994), plants with high levels of 2-tridecanone probably show antibiosis-type resistance mechanism and non-preference for oviposition and feeding type in relation to tomato pinworm.

\section{REFERENTES}

AZEVEDO, S.M.; MALUF, W.R.; FARIA, M.V.; OLIVEIRA, A.C.B.; RIBEIRO, C.A.; GONÇALVES-GERVÁSIO, R.C.; SANTACECÍLIA, L.V.C. Resistência à traça (Tuta absoluta) em genótipos de tomateiro com diferentes teores de sesquiterpenos nos folíolos. In: CONGRESSO BRASILEIRO DE OLERICULTURA, 39., Tubarão, 1999. Resumo. Tubarão: SOB, 1999. 38p.

BARBOSA, L.V. Controle genético e mecanismos de resistência em Lycopersicon spp à traça do tomateiro [Scrobipalpuloides absoluta (Meyrick, 1917) (Lep. Gelechiidae)]. Lavras: ESAL, 1994. 71p. (Dissertação - M.S.).
COELHO, M.C.F.; FRANÇA, F.H. Biologia e quetotaxia da larva e descrição da pupa e adulto da traça do tomateiro. Pesquisa Agropecuária Brasileira, v.22, p.129-135, 1987.

FOBES, J.F.; MUDD, J.B.; MARSDEN, M.P.F. Epicuticular lipid accumulation on the leaves of Lycopersicon pennellii (Corr. ) D'Arcy e Lycopersicon esculentum Mill. Plant Physiology, v.77, p.567-570, 1985.

HAJI, F.N.P.; OLIVEIRA, C.A.V.; AMORIM NETO, M.S.; BATISTA, J.G.S. Flutuação populacional da traça do tomateiro no submédio São Francisco. Pesquisa Agropecuária Brasileira, v.23, p.7-14, 1988.

LABORY, C.R. Repetibilidade, herdabilidade no sentido restrito e mecanismo de resistência do teor do aleloquímico 2- Tridecanona em Lycopersicon spp. À traça do tomateiro Scrobipalpuloides absoluta (Meyrick, 1917) Lepdoptera - Gelechidae. Lavras: UFLA, 1996. (Dissertação - M.S.).

LENKE, C.A.; MUTSCHLER, M.A. Inheritance of glandular trichomes in crosses between Lycopersicon esculentum and Lycopersicon pennellii. Journal of the American Society for Horticultural Science, v.109, p.592-596, 1984

MALUF, W.R.; BARBOSA, L.V.; COSTA SANTA-CECÍLIA, L.V. 2tridecanone - mediated mechanisms of resistance to the South American tomato pinworm Scrobipalpuloides absoluta (Meyrick, 1917) (Lepidoptera-Gelechiidae) in lycopersicon spp. Euphytica, v.93, p.189-194, 1997.

RESENDE, J.T.V.; CARDOSO, M.G.; MALUF, W.R.; SANTOS, C.D.; GONÇALVES, L.D.; RESENDE, L.V.; NAVES, F.O. Método colorimétrico para quantificação de acilaçúcar em genótipos de tomateiro. Ciência e Agrotecnologia, v.26, p.1204-1208, 2002.

Received December 06, 2004

Accepted December 19, 2005 